\title{
Sediment deposition and movement over a turf assemblage in a shallow rocky coastal area of the Ligurian Sea
}

\author{
Laura Airoldi ${ }^{1, *}$, Mauro Fabiano ${ }^{2}$, Francesco Cinelli ${ }^{1}$ \\ ${ }^{1}$ Dipartimento di Scienze dell'Ambiente e del Territorio, Università di Pisa, Via Volta 6, I-56126 Pisa, Italy \\ ${ }^{2}$ Facoltà di Scienze, Università di Ancona, Via Brecce Bianche, I-60100 Ancona, Italy
}

\begin{abstract}
The depositional environment over a turf assemblage of the rocky shore south of Livorno was studied from April 1992 to September 1993 by means of sediment traps positioned 50 and $200 \mathrm{~cm}$ above the turf surface. Changes in environmental conditions and in the intensity of terrestrial erosion and wind-wave resuspension of bottom sediments played a major role in controlling both the magnitude of sediment deposition and the nature of sedimented material, while limited responses to seasonal patterns of sedimentation of phytoplanktonic material were found. Mean rates of sediment deposition fluctuated between 1.6 and $52.4 \mathrm{~g} \mathrm{~m}^{-2} \mathrm{~d}^{-1}$, and the amount of trapped material decreased with distance from bottom, reflecting intense sediment resuspension and movement over the algal turf. The material sedimenting was mostly composed of small-size $(<200 \mu \mathrm{m})$ inorganic particles, and the organic material was characterized by the presence of highly degraded detritus. Besides faecal pellets few recognizable structures were found in the traps, such as charcoal fragments which probably originated from extensive burning of the coastal vegetation. Considerable variations in the intensity of the depositional environment over the algal turf were evident: the maxima sediment deposition and movement occurred in autumn and were related to heavy rainfall and wind-wave action, while in the summer the algal turf was generally free from sediment smother and scour. The ecological significance of these quantitative and qualitative temporal fluctuations is discussed, and the possible long-term impact of fire deforestation and increased soil erosion on turf structure and composition is hypothesized.
\end{abstract}

KEY WORDS: Sediment deposition - Resuspension - Algal turf · Rocky shore

\section{INTRODUCTION}

Sediment deposition and movement are likely to be some of the major physical factors influencing the structure, biomass and metabolism of seabed communities (Moore 1972, 1977, Mills 1975, Smetacek 1984). A significant part of the particulate organic carbon produced in the water column is channeled into the benthic food webs, and sediment fauna rapidly respond to fluctuations in the quantity and quality of sedimenting material by regulating its metabolic activity and growth (Graf et al. 1982, Graf 1987, Yap 1991, Relexans et al. 1992). Sedimentation greatly affects the composition and the ecology of coral reef communities

\footnotetext{
·E-mail: lairoldi@discat.unipi.it
}

(Rogers 1990, Wittenberg \& Hunte 1992), and excessive sediment loads may depress coral growth and survival by smothering coral tissues, by reducing light availability and coral capacity to capture food and even by preventing settlement and recruitment of coral larvae (Hunte \& Wittenberg 1992, Rice \& Hunter 1992). Seagrass species that develop vertical shoots may respond to fluctuations in sediment depth by modifying their vertical growth (Marbà \& Duarte 1994, Marbà et al. 1994). Coupling between fluctuations in sedimentation rates and the relative abundance of species has also been postulated for algal communities in temperate reefs (Littler et al. 1983, Stewart 1983, D'Antonio 1986). Monitoring the spatial and temporal variations in the rates of sediment deposition and movement is, therefore, one important step towards 
the understanding of patterns of distribution and abundance of benthic communities in many different habitats.

Despite some methodological uncertainties (Bloesh \& Burns 1980, Lee et al. 1983, Buesseler 1991), sediment traps have proved to be a powerful tool to directly assess the flux and the composition of particles in aquatic environments. In the last 30 years sediment traps of different sizes and shapes have been used with success to measure sedimentation rates in many oceanic (Honjo 1980, Deuser et al. 1981, Fellows et al. 1981, Fowler \& Knauer 1986) and soft-bottom coastal areas (Stephens et al. 1967, Peinert et al. 1982, Wassmann 1985, Bhosle et al. 1989. Hopcroft et al. 1990, Posedel \& Faganeli 1991, Puškaric et al. 1992). Results from these studies have produced evidence of large spatial and temporal fluctuations in the quantity and quality of total particle flux, which appear to be the response to a complex of hydrographical and biological processes. Among the principal factors that can influence the composition and flux of sedimenting matter in coastal areas are primary production (Peinert et al. 1982, Lignell et al. 1993), land erosion (Pocklington \& Leonard 1979) and wind-wave or tidal resuspension (Anderson \& Meyer 1986, Lund-Hansen 1991). Marked fluctuations of sedimentation rates may be observed in rocky coastal areas as well, with possible consequences for benthic communities (Daly \& Mathieson 1977, Littler et al. 1983, Stewart 1983, McQuaid \& Dower 1990). However, the role of sedimentation in these habitats has been largely neglected until recently, and sediment traps have rarely been used to assess the flux of particles on rocky shores (Gulliksen 1982, Rogers 1983, Bavestrello et al. 1991, Kendrick 1991).

The rocky shore south of Livorno, Italy (Western Mediterranean Sea) is characterized by turbid water. The benthic subtidal community of this area is strongly dominated by a filamentous algal turf (Airoldi et al. 1995). The prevalence of algal turfs in many rocky marine communities has been attributed, among other factors, to their ability to trap sediments (Sousa et al. 1981, Seapy \& Littler 1982, Stewart 1989). Sediment, in fact, is a structural constituent of algal turfs (Scoffin 1970, Stewart 1982, Kendrick 1991), and the characteristics of the depositional environment presumably influence the composition and the structure of the turfs themselves (Stewart 1983). In order to evaluate the importance of the depositional environment to the turf assemblage of the study area, the annual cycle of sediment deposition and movement over the turf was studied from April 1992 to September 1993 by means of sediment traps. The quantity and the quality of the sedimenting particulate material were investigated in relation to the properties of the water column and to meteorological conditions. The quantitative characterization of the depositional environment presented in this paper, together with the analysis of the composition and the seasonal dynamics of the algal turf which were carried out in parallel (Airoldi et al. 1995), provided the necessary background for the experimental investigations currently in progress devoted to addressing the role of sediment deposition and abrasion in maintaining and structuring the turf assemblage.

\section{MATERIAL AND METHODS}

Study site. The study site $\left(43^{\circ} 30^{\prime} \mathrm{N}, 10^{\circ} 20^{\prime} \mathrm{E}\right)$ is located about $10 \mathrm{~km}$ south of Livorno (Ligurian Sea), which is a highly industrialized and relatively large urban area as well as one of the most important ports in Italy (Fig, 1). Here the bottom consists of a gently sloping platform ot sandstone boulders covered by a dense filamentous algal turf (Airoldi et al. 1995). Sediment trap deployments were carried out at a depth of $14.5 \mathrm{~m}$, while hydrographical measurements were made approximately 200 min seawards from the sediment traps, on a muddy detritic bottom about $40 \mathrm{~m}$ in depth. Close to the study site, the high rocky cliffed coast is interrupted by a short arroyo of limited and intermittent flow, which forms a small detrital cone. The area is highly exposed to wave action and is

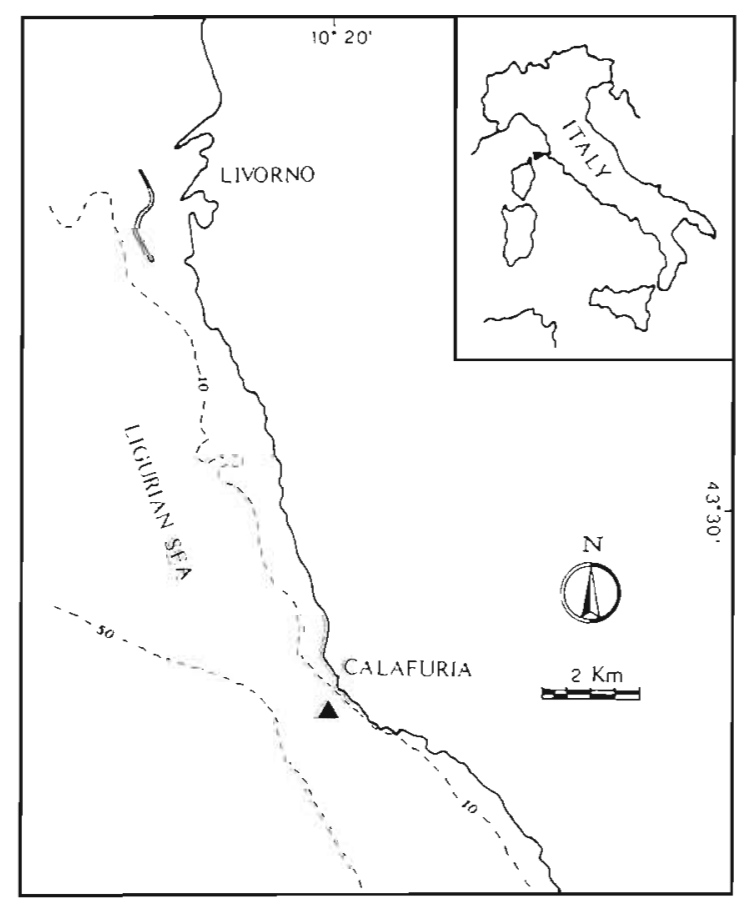

Fig. 1. Study area showing location of the sampling site 
open to winds from southeast (SE) to northwest (NW). The general circulation is little known and is probably rather complicated due to irregular coastal and bottom topography. The current along the coast is generally weak and mainly heads northwest; the flow, however, may completely reverse or interact with slow circular motions which cause a low renewal of the water mass (Gasparini et al. 1987). The area is at least partially affected by domestic and industrial wastes from the city of Livorno (Leoni et al. 1991a), and in recent years there has been a perceptible increase in the turbidity of the water, probably as a consequence of extensive burning of the coastal vegetation leading to greater soil erosion (see 'Discussion'). Further general information concerning the sedimentological and geomorphological characteristics of the coastal marine system off Livorno may be found in Gandolfi \& Paganelli (1975) and Leoni et al. (1991b).

Sampling. The vertical profiles of temperature and salinity at depth intervals of $0.5 \mathrm{~m}$ through the water column were recorded with a multiparametric probe (Idronaut Mod. 501) from November 1992 to October 1993. Daily precipitation rates and velocity of winds from SE to NW relative to the city of Livorno were provided throughout the research period by the Ufficio Idrografico e Mareografico of Pisa and by the Avvisatore Marittimo of Livorno respectively.

Sediment deposition and movement over the algal turf were measured using a trap system consisting of 2 sets of polypropylene cylindrical vessels positioned with their mouths at 50 and $200 \mathrm{~cm}$ respectively above the seafloor. Each vessel had a diameter of $51 \mathrm{~mm}$ and a height of $200 \mathrm{~mm}$ (aspect ratio: 3.9) and was held vertically stable by means of a stainless steel frame cemented to the bottom. The frame carried 4 irregularly arranged short ' $\mathrm{T}$ ' arms ( 2 for each depth) ending with 2 fixed PVC cylindrical tubes (diameter $60 \mathrm{~mm}$, height $150 \mathrm{~mm}$ ). The vessels were placed in the tubes and held in position by rubber bands. Three/four vessels were used at the same depth in order to estimate the variability between sediment traps. The traps were deployed from April 1992 to September 1993 during 16 periods ranging from 8 to 33 d (average 21), with 1 exceptional period of $44 \mathrm{~d}$. Deployment and retrieval of the vessels were carried out by SCUBA diving; vessels were closed with plastic stoppers during both operations. Some drops of chloroform were added in the field throughout the research period to reduce the impact of grazing and decomposition of organic material. The study was initially designed to run over 2 yr, until March 1994, but in October 1993 sampling was interrupted because a violent storm seriously damaged the frame, compromising further measurements as well as the last ones which had been carried out.
Chemical analysis. The material collected in each trap was passed through $200 \mu \mathrm{m}$ mesh to separate the coarse particles (hereafter coarse material: CM) from the finer ones (hereafter particulate material: TPM). The abundance and composition of both components was quantitatively assessed, and the total amount of material sedimenting over the algal turf was then expressed as their sum (total sediment deposition = CM + TPM)

The CM from 1 trap from each depth was preserved with buffered formalin in seawater $(5 \%)$ for microscopic analysis. A grid with 50 equally spaced dots was placed below the Petri dish where the material was being examined and contacts with each particle were counted under a stereomicroscope. The abundance of different kinds of particles was expressed as the percentage over the total number of contacts. The amount of CM from the remaining traps was determined gravimetrically on preweighed meshes (Krey 1964). The material was repeatedly rinsed with distilled water to remove salts and dried at $60^{\circ} \mathrm{C}$ for $24 \mathrm{~h}$ before weighing.

The smaller particles passing the mesh were resuspended in 1 l of filtered seawater (Sartorius SM 113, $0.2 \mu \mathrm{m}$ ) and kept homogeneous by agitation on a magnetic stirrer. Aliquots were withdrawn by pipetting from the suspension and filtered through precombusted $\left(450^{\circ} \mathrm{C}, 3 \mathrm{~h}\right) 25$ and $47 \mathrm{~mm}$ Whatman GF/F glass microfibre filters for the analysis described below. At least 3 replicates of each analysis were made. TPM was determined gravimetrically on preweighed filters in the same manner as CM. The fraction of particulate organic material (POM) was determined by weight loss on ignition at $450^{\circ} \mathrm{C}$ for $3 \mathrm{~h}$ (Dean 1974). The content of particulate inorganic material (PIM) was then calculated by subtraction (PIM = TPM - POM).

Particulate organic carbon (POC) and nitrogen (PON) were analyzed with a CHN analyzer (Carlo Erba Model 1108). To remove any carbonates the filters were treated with fumes of $\mathrm{HCl}$ for $5 \mathrm{~h}$ and dried prior to analysis (Hedges \& Stern 1984).

Chlorophyll a (chl a) and phaeopigments were extracted with $90 \%$ acetone and determined spectrophotometrically before and after treatment with dilute $\mathrm{HCl}$ (Strickland \& Parsons 1972). The presence of chloroform degrades some of the chlorophylls to phaeopigments during trap exposure (Hendrikson 1976, Gundersen \& Wassmann 1990). The pigment content was, therefore, expressed as chl a equivalents (chl $\mathrm{a}$ eq), that is, the sum of $\mathrm{chl} a$ and phaeopigment content (Smetacek 1980).

The amount of TPM, POM and PIM were measured throughout the research period (April 1992 to September 1993), while the content of CM was investigated from July 1992 onward and those of POC, PON and chloropigments from April 1992 to June 1993. 


\section{RESULTS}

\section{Hydrography and meteorological conditions}

Temperature of the surface water varied from $13.3^{\circ} \mathrm{C}$ in February/March to $25.1^{\circ} \mathrm{C}$ in August (Fig. 2A.). The range of these fluctuations generally decreased with depth. Temperature greatly influenced the vertical mixing of the water column. From November to May temperatures were homogeneous from the surface to the bottom, implying intense mixing of the water column. From May onward, with the development of warmer and stabler meteorological conditions, the surface water temperature increased. The effect of this summer warming penetrated to $15-25 \mathrm{~m}$ in depth, making the water column thermally stratified from June to September. This stable situation broke up at the end of October, when cold northeast winds caused a drop in surface temperature.

Surface salinity was maximal in February (38\%) and minimal in June $(37.5 \%)$, when a slight saline stratification of the water column developed in parallel to the thermal one (Fig. 2B). The fluctuations of the sainity were very limited, probably due to the low riverine input into the area.

Rainfall averaged over the various periods of deployment of sediment traps was generally lower than $3 \mathrm{~mm}$ $\mathrm{d}^{-1}$, with 1 exceptional peak in September/October 1992, while winds from SE to NW showed major temporal fluctuations in mean velocity (Fig. 3A).

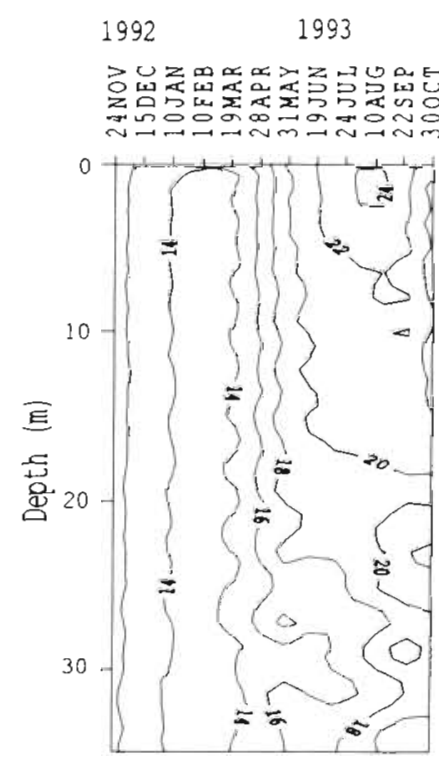

A
1992

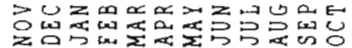

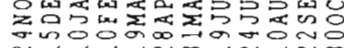

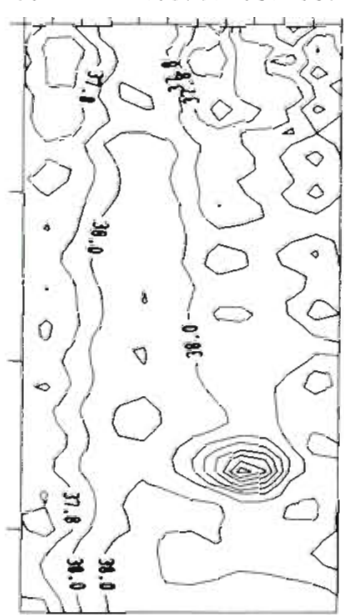

B
Fig. 2. Vertical profiles of $(A)$ temperature $\left({ }^{\circ} \mathrm{C}\right)$ and $(B)$ salinity $(\%)$ measured at depth intervals of $0.5 \mathrm{~m}$ along the water column from Novenber 1992 to October 1993
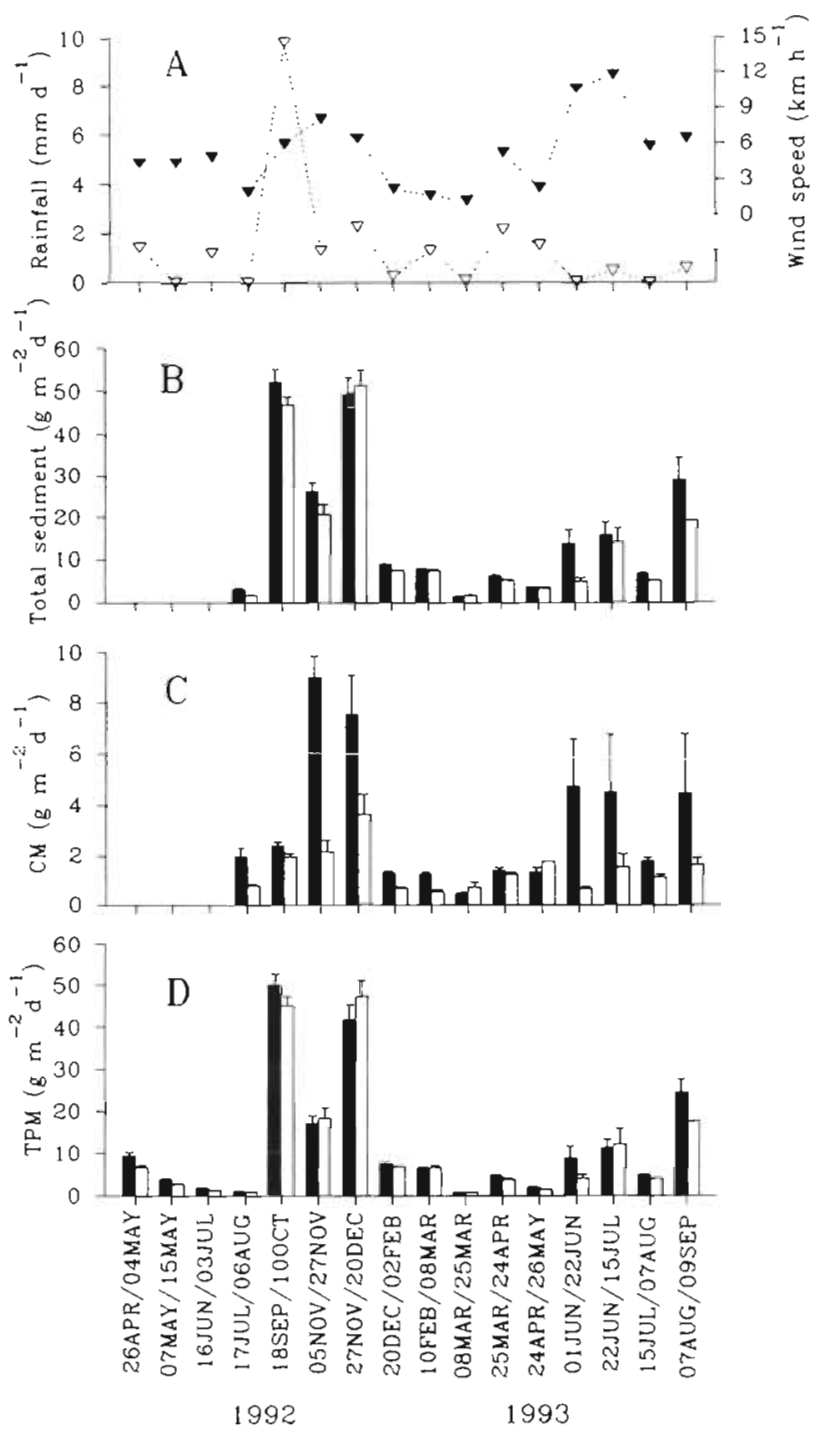

Fig. 3. (A) Mean rainfall ( $m \mathrm{~d}^{-1}$, left axis $\nabla$ ) and speed of winds from SE to NW $\left(\mathrm{km} \mathrm{h}^{-1}\right.$, right axis $\left.\boldsymbol{\nabla}\right)$; and mean rates of deposition (+1 SE, $3<\mathrm{n}<4, \mathrm{~g} \mathrm{~m}^{-2} \mathrm{~d}^{-1}$ ) at $50 \mathrm{~cm}$ (ם) and $200 \mathrm{~cm}$ $(\square)$ above the turf surface of: (B) total sediment, (C) coarse material (CM) and (D) particulate material (TPM) during various periods of deployment of sediment traps from April 1992 to September 1993. Rainfall and wind speed data refer to the near city of Livorno; wind velocities were measured at 06:00 h

\section{Depositional environment}

\section{Sediment trapped in relation to depth}

The amount of total sediment trapped greatly differed with depth (Fig. 3B). Traps in proximity of the seafloor, in fact, generally collected more material then those located $1.5 \mathrm{~m}$ above in the water column, suggesting high resuspension of particles from the bottom and sediment movement over the algal turf The differ- 


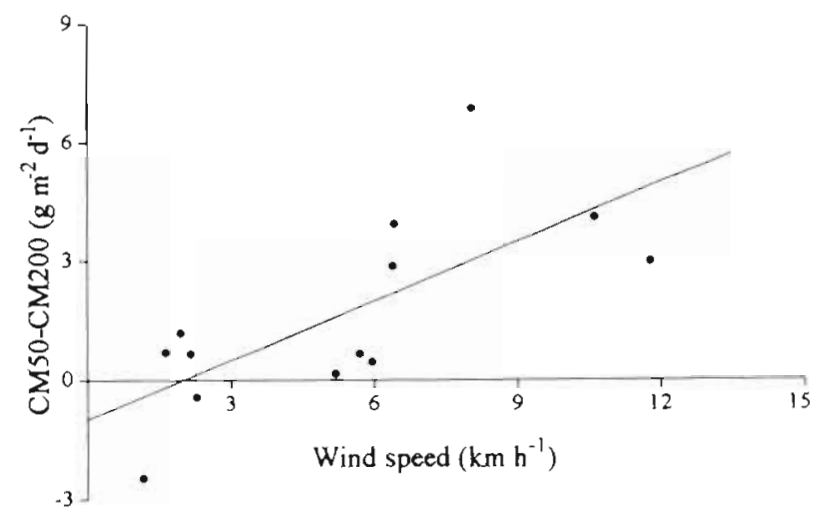

Fig. 4. Regression of the differences in flux of coarse material between 50 and $200 \mathrm{~cm}$ above the seafloor (CM50-CM200, $\mathrm{g}$ $\left.\mathrm{m}^{-2} \mathrm{~d}^{-1}\right)$ on the mean speed $\left(\mathrm{km} \mathrm{h}^{-1}\right)$ of winds from SE to NW averaged over the exposure time of the traps. The regression line is described by the equation:

$\mathrm{CM} 50-\mathrm{CM} 200=0.5$ (wind speed) $-1, \mathrm{R}^{2}=0.5, \mathrm{n}=13$

ences with depth mainly concerned the amount of CM (Fig. 3C) and were significantly correlated with wind velocity $\left(\mathrm{R}^{2}=0.5, \mathrm{p}<0.01\right.$, Fig. 4). Conversely, the abundance of TPM was rather uniform with depth (Fig. 3D), probably because the resuspension of these finer particles generally involved all the water column above the sediment traps. No differences were observed in the composition of the material collected at the 2 depths, except for the relative content of faecal pellets of the CM (Fig. 5), which was significantly higher in bottom traps $(p<0.05$, Student's t-test, $\mathrm{n}=13)$.

\section{Temporal pattern}

Marked temporal fluctuations in mean rates of total sediment deposition over the algal turf were observed at both depths. During the period of investigation the amount of total material collected varied from 3.1 to $52.4 \mathrm{~g} \mathrm{~m}^{-2} \mathrm{~d}^{-1}$ and from 1.6 to $51.1 \mathrm{~g} \mathrm{~m}^{-2} \mathrm{~d}^{-1}$ in bottom and upper traps respectively (Fig. 3B); these differences reflected fluctuation both of CM and TPM (Fig. 3C, D). A seasonal pattern was evident: the maximum sediment deposition occurred in autumn and was probably related to both heavy rainfall and windinduced wave action, while in the summer the algal turf was generally free from sediment burial.

Mean sedimentation rates of chl a eq were lowest from May to August 1992 and highest from September 1992 to March 1993 (Fig. 6). The relatively higher fluxes measured during November/December 1992 were probably related to the wind-wave resuspension of bottom detritus containing organic material produced by grazing of zooplankton or suspension feed-

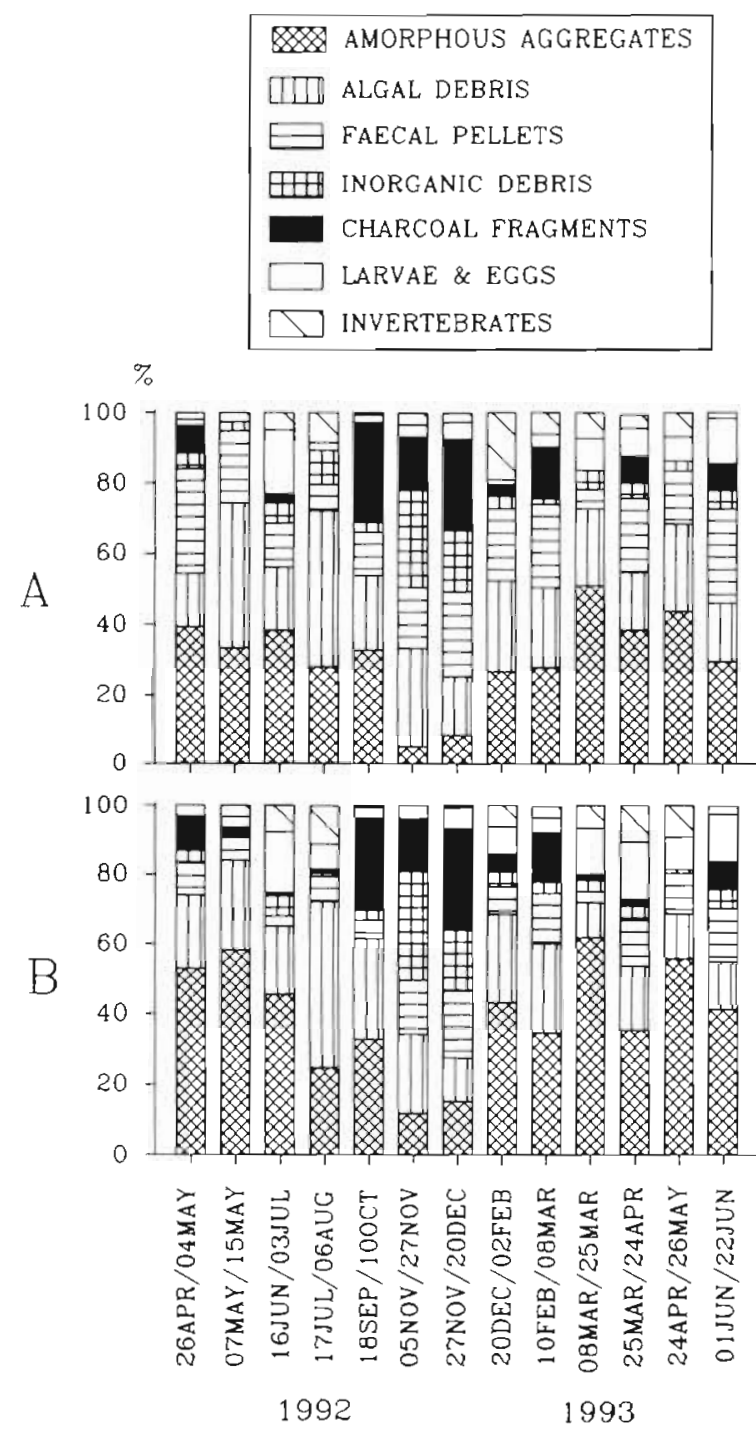

Fig. 5. Percentage composition of coarse material (CM) collected with sediment traps (A) $50 \mathrm{~cm}$ and (B) $200 \mathrm{~cm}$ above the turf surface during various periods of deployment from April 1992 to June 1993

ing organisms. Conversely, the peaks measured in April 1992 and January/February 1993 presumably indicate inputs of fresh phytodetritus from surface primary production.

\section{Nature of trapped particles}

The microscopic quantitative analysis revealed that most of the CM found in the sediment traps from both depths consisted of amorphous aggregates, algal detritus and oval or cylindrical faecal pellets (Fig. 5). Eggs, larvae and a variety of juvenile benthic invertebrates, such as crustaceans, gastropods and clams, 


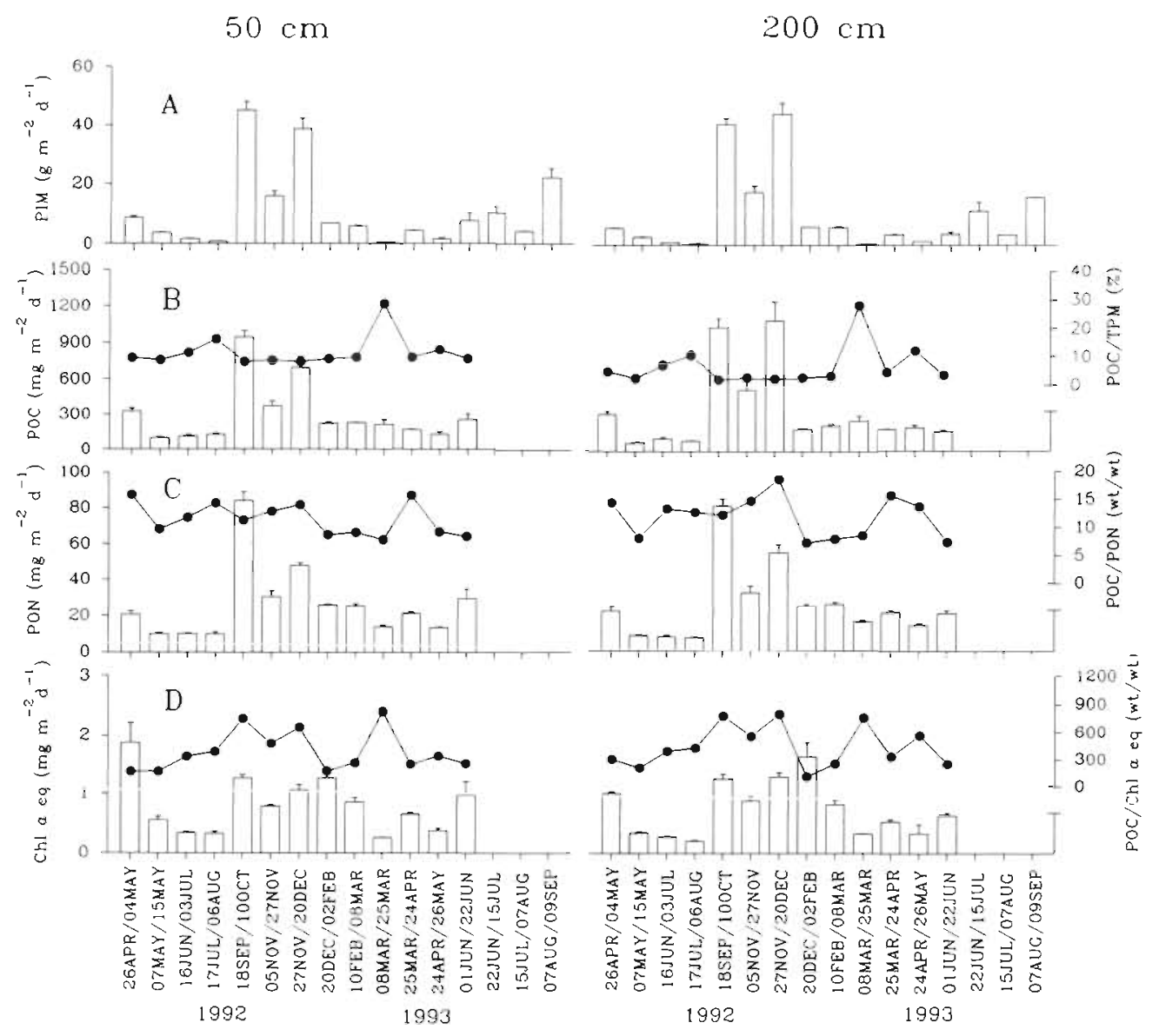

Fig. 6. Sedimentation rates ( $+1 \mathrm{SE}, 3<\mathrm{n}<4$, left axes, bars) of (A) particulate inorganic material (PIM), (B) particulate organic carbon (POC). (C) particulate organic nitrogen (PON) and (D) chl a equivalents (chl a eq); and (right axes, line graphs) (B) POC/ particulate material (TPM), (C) POC/PON and (D) POC/chl a eq ratios of sedimented material 50 and $200 \mathrm{~cm}$ above the turf surface from April 1992 to September 1993

were present especially during spring and summer months. Occasionally adult benthic invertebrates were also found in the traps, mainly gastropods. In November and December 1992 a large fraction of the CM consisted of inorganic detritus, especially grains of sand. Charcoal fragments were found in the traps throughout the research period and were especially abundant from September to December 1992, when precipitation and consequent erosion from land were most intense.

The major part (57 to $95 \%$ ) of the TPM collected by sediment traps at both depths was composed of the inorganic fraction (Fig. 6A). The relative mean POC content of TPM was 1.7 to $27 \%$ (average 6.1 , $\mathrm{n}=26$, Fig. $6 \mathrm{~B}$ ) with a $\mathrm{POM} / \mathrm{POC}$ ratio between 1.5 and 4.9. Small seasonal variations were observed, implying very little influence of phytoplanktonic production with respect to other sources of POC, such as resuspension of bottom sediments, inflow of eroded material from land or import of domestic sewage.
Confirmation of this comes from the high values of the POC/chl a eq (wt/wt) ratio measured throughout the investigation (Fig. 6D). This ratio should estimate the relative content in plant pigments of organic detritus and, according to Zeitzschel (1970), values of 100 or less should indicate important inputs of fresh phytodetritus. The POC/chl a eq ratios measured at our study site were higher than 200 during most of the year, reaching values as high as -800 during October/December 1992 and March 1993. The lower ratios were observed in April/May 1992 and January/February 1993 (175 and 105 respectively)

The POC/PON ratio of the trapped material was always rather high and showed modest variations with season (Fig. 6C). Low values for the POC/PON ratio suggest consistent inputs of fresh phytodetritus, whereas values greater than 7 imply an ageing of the organic material or a contribution from terrestrial sources (Parsons 1975, Pocklington \& Leonard 1979, Poulet et al. 1986). The POC/PON ratios from our rocky 
site ranged between 7.2 and 18.5 (average $11.7, \mathrm{n}=26$ ) suggesting once again important deposition over the turf of terrestrial and resuspended detritus.

\section{DISCUSSION}

High levels of sediment deposition have been implicated as detrimental to species richness and diversity of hard bottom communities in a number of studies (Neushul et al. 1976, Daly \& Mathieson 1977, Seapy \& Littler 1982, Engledow \& Bolton 1994), and the prevalence of algal turfs in many intertidal and subtidal rocky habitats has been suggested to be related to prolonged high levels of sediment burial and scour (Thom \& Widdowson 1978, Taylor \& Littler 1982, Stewart 1989). Mean rates of total sediment deposition over the turf assemblage of the study area fluctuated between 1.6 and $52.4 \mathrm{~g} \mathrm{~m}^{-2} \mathrm{~d}^{-1}$. These values are moderately high if compared with sedimentation rates measured with sediment traps in other shallow coastal areas
(Table 1). However, great care needs to be taken when interpreting the composition and structure of benthic communities as a response to 'high' or 'low' levels of sedimentation, especially when comparing results from different sites and/or measured with sediment traps of various sizes and shapes. Laboratory and in situ experiments, in fact, have shown that the collection efficiency of a sediment trap in moving water is primarily a function of its geometry (Gardner 1980a, b, Butman 1986), and stable, vertically suspended, smooth cylinders, with an inner diameter of more than $45 \mathrm{~mm}$ and an aspect ratio of more than 3 like those used in the present study, give the most reliable results (Bloesh \& Burns 1980, Blomqvist \& Kofoed 1981, Butman et al. 1986). Moreover, traps placed just above the substrate collect more sediment than those higher in the water column (Young \& Rhoads 1971, Bovée \& Delille 1980) and sedimentation rates measured in highly energetic habitats are more affected by bottom resuspension than those from sheltered areas (Smetacek 1984, Lund-Hansen 1991). To date sediment

Table 1. Rates of sediment deposition $\left(\mathrm{g} \mathrm{m}^{-2} \mathrm{~d}^{-1}\right)$ measured with sediment traps in different shallow water coastal environments

\begin{tabular}{|c|c|c|c|c|}
\hline $\begin{array}{l}\text { Location } \\
\text { Bottom characteristics }\end{array}$ & $\begin{array}{l}\text { Bottom } \\
\text { depth (m) }\end{array}$ & $\begin{array}{l}\text { Height of traps } \\
\text { above the bottom (m) }\end{array}$ & $\begin{array}{l}\text { Sediment deposition } \\
\qquad\left(\mathrm{g} \mathrm{m}^{-2} \mathrm{~d}^{-1}\right)\end{array}$ & Source \\
\hline $\begin{array}{l}\text { Cape Cod Bay, Massachusetts, USA } \\
\text { Sand }\end{array}$ & 12 & $\begin{array}{l}0.2 \\
0.5 \\
0.8\end{array}$ & $\begin{array}{r}\text { ca } 18 \\
\text { ca } 10 \\
\text { ca } 8\end{array}$ & Young \& Rhoads (1971) \\
\hline $\begin{array}{l}\text { Discovery Bay, Jamaica } \\
\text { Reef lagoon }\end{array}$ & 4 & 0.5 & $5-11$ & Dodge et al. (1974) \\
\hline $\begin{array}{l}\text { Banyuls sur Mer, France } \\
\text { Mud }\end{array}$ & 32.5 & $\begin{array}{l}1 \\
1.5 \\
2.5\end{array}$ & $\begin{array}{l}10.4-82.5 \\
22.6-114.7 \\
12.1-73.9\end{array}$ & Bovée \& Delille (1980) \\
\hline $\begin{array}{l}\text { Kiel Bight, Baltic Sea } \\
\text { Soft sediment }\end{array}$ & 20 & $\begin{array}{l}2 \\
5\end{array}$ & $\begin{array}{l}1.7-5 \\
1.8-5\end{array}$ & Smetacek (1980) \\
\hline $\begin{array}{l}\text { Kiel Bight, Baltic Sea } \\
\text { Soft sediment }\end{array}$ & 20 & 2 & ca $0.1-349$ & Peinert et al. (1982) \\
\hline $\begin{array}{l}\text { St Thomas, USVI } \\
\text { Coral reef }\end{array}$ & $3-5$ & $\begin{array}{l}0.1 \\
0.5\end{array}$ & $\begin{array}{l}8 \pm 4-58 \pm 133 \\
1 \pm 1-16 \pm 7\end{array}$ & Rogers (1982) \\
\hline $\begin{array}{l}\text { Puesto Rico } \\
\text { Back reef }\end{array}$ & 4 & $\begin{array}{l}0.1 \\
0.5\end{array}$ & $\begin{array}{c}96 \pm 24 \\
25 \pm 9-26 \pm 12\end{array}$ & Rogers (1983) \\
\hline $\begin{array}{l}\text { Paraggı Bay, Italy } \\
\text { Rocky cliff }\end{array}$ & 24 & 8 & $11.9-129.7$ & Bavestrello et al. (1991) \\
\hline $\begin{array}{l}\text { Academy Bay, Galapagos } \\
\text { Reef lagoon }\end{array}$ & $<2$ & 0.5 & $100-550$ & Kendrick (1991) \\
\hline $\begin{array}{l}\text { Western Baltic Sea } \\
\text { Soft sediment }\end{array}$ & $10.5-16$ & 1 & $0.2-13.3$ & Lund-Hansen (1991) \\
\hline $\begin{array}{l}\text { Gulf of Trieste, Italy } \\
\text { Soft sediment }\end{array}$ & 17 & 1 & $10-108$ & Posedel \& Faganelli (1991\} \\
\hline $\begin{array}{l}\text { Northern Adriatic, Italy } \\
\text { Soft sediment }\end{array}$ & $32-37$ & 2 & $2.1-41.3$ & Puškaric et al. (1992) \\
\hline $\begin{array}{l}\text { Ligurian Sea, Italy } \\
\text { Sandstone boulders covered } \\
\text { by an algal turf }\end{array}$ & 14.5 & $\begin{array}{l}0.5 \\
2\end{array}$ & $\begin{array}{l}3.1-52.4 \\
1.6-51.1\end{array}$ & Present work \\
\hline
\end{tabular}


deposition on rocky shores has rarely been quantified and characterized with sediment traps (Gulliksen 1982, Rogers 1983, Bavestrello et al. 1991, Kendrick 1991), and responses of rocky bottom communities to different sedimentation levels are not well known, because of the lack of direct experimental research (but see Kendrick 1991).

The quantitative analysis of the composition of the material sedimenting over the algal turf at our study site showed that it was mostly composed of small-size particles $(<200 \mu \mathrm{m})$, which accounted for 36 to $96 \%$ (average $76 \%, \mathrm{n}=26$ ) of total trapped sediment at both depths. These fine particles were characterized by a high content of the inorganic fraction, always more than $57 \%$, and by POC/PON ratio values generally higher than 9, which both provide evidence of consistent inputs of terrestrial sediments (Pocklington \& Leonard 1979, Faganeli et al. 1988, Navarro et al. 1993). Terrigenous addition to sedimenting material is also suggested by the major TPM sedimentation rates which were measured in correspondence with heavy rainfall and possible consequent erosion from land. In 1990 the study area was hit by extensive fires involving the coastal vegetation, and a pronounced increase of water turbidity close to the shore was noticed in the following years (Airoldi \& Cinelli pers. obs.). This is presumably a consequence of greater soil erosion and particulate transport. Increased water turbidity and sediment load may be potential critical sources of stress and disturbance for rocky shore communities (Daly \& Mathieson 1977, Seapy \& Littler 1982, Lumb 1990, Shaffer \& Parks 1994), and prolonged sediment smothering may have a more extensive impact than short-term deep burial by sediments (Marszalek 1981, Rogers 1990). Algal turfs at our study site were never buried by sediments during the period of investigation, but a possible long-term impact of fire deforestation and runoff of eroded soils on sedimentation rates is suggested by the large amounts of charcoal fragments found in the sediment traps even 3 yr after the fire event.

Mean sediment deposition measured throughout the investigation was generally higher in the proximity of the seafloor than $1.5 \mathrm{~m}$ above in the water column. Increasing sedimentation rate with depth seems to be a typical feature of many shallow coastal marine systems, where resuspension of bottom sediments, induced by wind or storm waves, contributes considerably to sedimented particulate material (Young \& Rhoads 1971, Hargrave \& Taguki 1978, Smetacek et al. 1978, Bovée \& Delille 1980, Gulliksen 1982, Liebezeit \& Bodungen 1987, Puškaric et al. 1992). This contrasts with the usual situation in open-ocean systems, where surface water productivity is often the chief source of sinking particles (Knauer et al. 1978, Honjo 1980,
Deuser et al. 1981). At our study site evidence of resuspension was provided by the sand grains collected by sediment traps at both depths as well as by the high POC/PON ratios, suggesting inputs of degraded organic material from bottom sediments (Parsons 1975, Navarro et al. 1993). Decrease in flux with distance from the bottom may give quantitative information on resuspension rates and consequently on sediment movement in the habitat (Bloesh 1994, Kozerski 1994). During the investigation the amount of CM decreased 10 to $86 \%$ (average $37 \%, n=26$ ) from bottom to upper traps, and the differences among depths were significantly correlated with wind velocity, which is a good indicator of water turbulence for the study area. This result suggests intense sediment movement over the algal turf. Resuspension probably also involved the finer particles, although no marked decrease of TPM flux was observed with depth, possibly because the process affected a major part, if not all, of the wator column above the sediment traps.

On exposed rocky habitats, like those in this study, sediment deposition and movement are often comvilied düe to high turbulcnt flow near the bottom, but the effects they have on benthic communities (i.e. smothering and scouring respectively) are different and should be distinguished (Taylor \& Littler 1982 , D'Antonio 1986, Kendrick 1991). Sediment smothering involves reduced availability of light, oxygen, nutrients and firm substratum for settlement and recruitment while scouring may remove whole organisms or their parts (Daly \& Mathieson 1977, Devinny \& Volse 1978). The degree and duration of sediment burial as well as the strength of water motion determine the intensity of the perturbation. Seasonal variations in rates of sediment deposition and movement and in the quality of sedimenting material can, therefore, be presumed to affect the composition and structure of the biota, and coupling between fluctuations in sedimentation levels and the relative abundance of algal species has been postulated for algal communities in temperate reefs (Littler et al. 1983, Stewart 1983, D'Antonio 1986). The rates of sediment deposition over the turf assemblage on the rocky shore south of Livorno showed marked qualitative and quantitative temporal fluctuations. These largely reflected changes in environmental conditions and in the intensity of land erosion and windwave resuspension of bottom sediments, while seasonal patterns of sedimentation of primary material made only a small contribution. In particular, during the investigation period, it was possible to identify 3 distinct situations which may represent different levels of perturbation for the algal turf:

(1) In fair weather sediment deposition and movement were relatively low and the algal turf was mostly free from sediment smother and scour. These condi- 
tions occurred mainly in spring and summer, when increasing stabilization of the water column reduced bottom turbulence and vertical mixing. The composition of the sedimenting material could, therefore, benefit from a slight increase in POC and plant pigments due to higher superficial phytoplankton growth. although the relative input from primary production to total sediment flux in the study area was low compared to other shallow temperate coastal areas (Smetacek et al. 1978, Smetacek 1980, Peinert et al. 1982, Puškaric et al. 1992, Navarro et al. 1993).

(2) In rainy weather the coast was heavily eroded, and large amounts of terrestrial material were transported seaward and sank over the algal turf, as testified to by the abundant charcoal fragments found in the sediment traps. The finer fraction predominated, and the content of organic material was rather low. The organic carbon was characterized by high values of the POC/PON ratios, which indicated the presence of compounds refractory to microbial degradation, like wood debris containing lignin (Pocklington \& Leonard 1979). The high sediment loads from terrestrial origin which characterized the period of October/November 1992 caused transient conditions of partial burial of the algal turf by a thin sediment layer (Airoldi pers. obs.), with possible smothering effects.

(3) During storms or windy weather bottom sediments were resuspended by water turbulence, as testified to by the increasing trapping rates of CM with depth and by the abundance of sand grains found in the sediment traps. The content of organic material was quite low, and its composition reflected the presence of highly degraded detritus. Resuspension likely involved both sediment from soft-bottom areas interspersed through the boulders colonized by the turf as well as sediment deposited over or entrapped in the turf itself. During these periods, therefore, scouring effects due to sediment movement in the habitat were probably high, as suggested also by the marked decrease in the thickness of the algal turf which was observed after the prolonged storms which occurred in November/December 1992 (Airoldi et al. 1995).

Although the wide temporal fluctuations in the characteristics and intensity of the depositional environment probably affected the thickness of the algal turf, its composition and structure remained constant during the period of investigation (Airoldi et al. 1995). This result contrasts with observations from other authors (Littler et al. 1983, Stewart 1983) and suggests that, together with sediment deposition and movement, other physical and/or biotic factors could play a role in structuring the algal turf of the study area. This hypothesis warrants further multifactorial experiments that include observations on biotic interactions. Longterm studies, including analysis at different spatial and temporal scales, are also necessary to document year to year variations in sediment loads and to evaluate the potential importance of fire deforestation and runoff of eroded soils in determining the persistence and composition of the algal turf.

Acknowledgements. We are grateful to Prof. A. J. Southward, Prof. S. J. Hawkins and 2 anonymous referees for their helpful comments on the manuscript and to Prof. N. Della Croce who provided space and facilities at the Institute of Marine Environmental Science of the University of Genova. Help in the laboratory was given by R. Bruzzone and P. Povero. We also thank the Guardia di Finanza of Livorno and D. Bertolini for assistance in the field. The study was completed as a portion of the doctoral thesis research of L.A. at the University of Genova, Italy

\section{LITERATURE CITED}

Airoldi L, Rindi F, Cinelli F (1995) Structure, seasonal dynamics and reproductive phenology of a filamentous turf assemblage on a sediment influenced, rocky subtidal shore. Bot Mar 38:227-237

Anderson FE, Meyer LM (1986) The interaction of tidal currents on a disturbed intertidal bottom with a resulting change in particulate matter quantity, texture and food quality. Estuar Coast Shelf Sci 22:19-29

Bavestrello G, Cattaneo-Vietti R, Danovaro R, Fabiano M (1991) Detritus rolling down a vertical cliff of the Ligurian Sea (Italy): the ecological role in hard bottom communities. PSZN I: Mar Ecol 12:281-292

Bhosle NB, Sawant SS, Sankaran PD, Wagh AB (1989) Sedimentation of particulate material in stratified and nonstratified water columns in the Bombay High area of the Arabian Sea. Mar Ecol Prog Ser 57:225-236

Bloesch J (1994) A review of methods used to measure sediment resuspension. Hydrobiologia 284:13-18

Bloesch J, Burns NM (1980) A critical review of sedimentation trap technique. Schweitz Z Hydrol 42:15-55

Blomqvist S, Kofoed C (1981) Sediment trapping-a subaquatic in situ experiment. Limnol Oceanogr 26:585-590

Bovee F de, Delille D (1980) Origine et importance des apports sestoniques au niveau des communautés benthiques des vases terrigènes côtiéres de Banyuls-sur-Mer Vie Milieu 30:97-104

Buesseler KO (1991) Do upper-ocean sediment traps provide an accurate record of particle flux? Nature 353:420-423

Butman CA (1986) Sediment trap biases in turbulent flow result from a laboratory study. J Mar Res 44:645-693

Butman CA, Grant WD, Stolzenbach KD (1986) Predictions of sediment trap biases in turbulent flows: a theoretical analysis based on observations from the literature. J Mar Res 44:601-644

Daly MA, Mathieson AC (1977) The effect of sand movement on intertidal seaweeds and selected invertebrates at Bound Rock, New Hampshire, USA. Mar Biol 43:45-55

D'Antonio CM (1986) Role of sand in the domination of hard substrata by the intertidal alga Rhodomela larix. Mar Ecol Prog Ser 27:263-275

Dean WE Jr (1974) Determination of carbonate and organic matter in calcareous sediments and sedimentary rocks by loss on ignition: comparison with other methods. J Sedim Petrol 44:242-248

Deuser WG, Ross EH, Anderson RF (1981) Seasonality in the supply of sediment to the deep Sargasso Sea and implica- 
tions for the rapid transfer of matter to the deep ocean. Deep Sea Res 28:495-505

Devinny JS, Volse LA (1978) The effect of sediments on the development of Macrocystis pyrifera gametophytes. Mar Biol 48:343-348

Dodge RE, Aller RC. Thompson J (1974) Coral growth related to resuspension of bottom sediments. Nature 247:574-577

Engledow HR, Bolton JJ (1994) Seaweed $\alpha$-diversity within the lower eulitoral zone in Namibia: the effects of wave action, sand inundation, mussels and limpets. Bot Mar 37 : $267-276$

Faganeli J, Malej A, Pezdic J, Malacic V (1988) C:N:P ratios and stable $C$ isotopic ratios as indicators of sources of organic matter in the Gulf of Trieste (Northern Adriatic). Oceanol Acta 11:377-382

Fellows DA, Karl DM, Knauer GA (1981) Large particle fluxes and the vertical transport of living carbon in the upper $1500 \mathrm{~m}$ of the northeast Pacific Ocean. Deep Sea Res 28: $921-936$

Fowler SW, Knauer GA (1986) Role of large particles in the transport of elements and organic compounds through the oceanic water column. Prog Oceanogr 16:147-194

Gandolfi G, Paganelli L (1975) Il litorale toscano fra Livorno e il promontorio di Piombino (Area campione Alto Tirreno). Composizione provenienza e dispersione delle sabbie. Boll Soc Geol It 94:1833-1854

Gardner WD (1980a) Sediment trap dynamics and calibration: a laboratory evaluation. J Mar Res 38:17-39

Gardner WD (1980b) Field assessment of sediment traps. J Mar Res 38:41-52

Gasparini GP, Marri P, Rossi C. Dell'Amico S (1987) Il sistema marino livornese. Caratteristiche delle masse d'acqua. Atti del I Convegno sullo stato dell'Ambiente a Livorno, 7-8 Nov 1986, p 177-178

Graf $G$ (1987) Benthic energy flow during a simulated autumn bloom sedimentation. Mar Ecol Prog Ser 39:23-29

Graf G, Bengtsson W. Diesner U, Schuiz R, Theede H (1982) Benthic response to sedimentation of a spring phytoplankton bloom: process and budget. Mar Biol 67:201-208

Gulliksen B (1982) Sedimentation close to a near vertical rocky wall in Balsfjorden, northern Norway. Sarsia 67: $21-27$

Gundersen K, Wassmann P (1990) Use of chloroform in sediment traps: caution advised. Mar Ecol Prog Ser 64: $1.87-195$

Hargrave BT, Taguchi S (1978) Origin of deposited material sedimented in a marine bay. J Fish Res Bd Can 35: $1604-1613$

Hedges JI, Stern JH (1984) Carbon and nitrogen determınations of carbonate-containing solids. Limnol Oceanogr 29: $657-663$

Hendnkson P (1976) Abbauraten von organischem Kohlenstoff im Seston und in Sinkstoffen der Kieler Bucht. Kieler Meeresforsch 3:105-119

Honjo S (1980) Material fluxes and modes of sedimentation in the mesopelagic and bathypelagic zones. J Mar Res 38: $53-97$

Hopcroft RR, Roff JC, Berges JA (1990) Size-fractionated sedimentation in a tropical neritic ecosystem near Kingston, Jamaica. Cont Shelf Res 10:795-806

Hunte W, Wittenberg M (1992) Effects of eutrophication and sedimentation on juvenile corals. II. Settlement. Mar Biol 114:625-631

Kendrick GA (1991) Recruitment of coralline crusts and filamentous turf algae in the Galapagos archipelago: effect of simulated scour, erosion and accretion. J Exp M.ar Biol Ecol 147:47-63
Knauer GA, Martin JH, Bruland KW (1978) Fluxes of particulate carbon, nitrogen and phosphorous in the upper water column of the northeast Pacific. Deep Sea Res 35: $1223-1234$

Kozerskı HP (1994) Possibilities and limitations of sediment traps to measure sedimentation and resuspension. Hydrobiologia 284:93-100

Krey I (1964) Die mittlere Tiefenverteilung von Seston Mikrobiomasse und detritus in nördlichen Nordatlantik. Kieler Meeresforsch 20:18-29

Lee C, Wakeham SG, Farrington JW (1983) Variations in the composition of particulate organic matter in a time series sediment trap. Mar Chem 13:181-194

Leoni L, Sartori F, Damiani V, Ferretti O, Viel M (1991a) Trace element distributions in surficial sediments of the northern Tyrrhenian Sea: contribution to heavy-metal pollution assessment. Environ Geol Water Sci 17:103-116

Leoni L, Sartori F, Saitta M, Damiani V, Ferretti O, Viel M (1991b) Mineralogy, chemistry, and grain size composition of recent sediments in the northern Tyrrhenian Sea: contribution to the study of sediment transport and distribution. Environ Geol Water Sci 17:23-46

Liebezeit $G$, Bodungen $B$ von (1987). Biogenic fluxes in the Bransfield Strait: planktonic versus macroalgal sources. Mar Ecol Prog Ser 36:23-32

Lignell R, Heiskanen AS, Kuosa $H_{i}$ Gundersen K, KuuppoLeinikki P, Pajuniemi R, Uitto A (1993) Fate of a phytopiankion spring bluoul sedimentation and carbon flow in the planktonic food. web in the northern Baltic. Mar Ecol Prog Ser 94:239-252

Littler MM. Martz DR, Littler DS (1983) Effects of recurrent sand deposition on rocky intertidal organisms: importance of substrate heterogeneity in a fluctuating environment. Mar Ecol Prog Ser 11:129-139

Lumb CM (1990) Algal depth distributions and long-term turbidity changes in the Menai Strait, North Wales. Prog Underwat Sci 15:85-99

Lund-Hansen LC (1991) Sedimentation and sediment accumulation rates in a low-energy embayment. J Coast Res 7:969-980

Marbà N, Cebrián J, Enríquez S, Duarte CM (1994) Migration of large scale bedforms measured with seagrasses [Cymodocea nodosa) as tracers. Limnol Oceanogr 39: 126-133

Marbà N, Duarte CM (1994) Growth response of the seagrass Cymodocea nodosa to experimental burial and erosion. Mar Ecol Prog Ser 107:307-311

Marszalek DS (1981) Impact of dredging on a subtropical reef community, Southeast Florida, U.S.A. Proc 4th Int Coral Reefs Congr 1:147-153

McQuaid C, Dower KM (1990) Enhancement of habitat heterogeneity and species richness on rocky shores inundated by sand. Oecologia 84:142-144

Mills EL (1975) Benthic organisms and the structure of marine ecosystems. J Fish Res Bd Can 32:1657-1663

Moore PG (1972) Particulate matter in the subluttoral zone of an exposed coast and its ecological significance with special reference to fauna inhabiting kelp holdfasts. J Exp Mar Biol Ecol 10:59-80

Moore PG (1977) Inorganic particulate suspensions in the sea and their effects on marine animals. Oceanogr Mar Biol A. Rev 15:225-363

Navarro JM, Clasing E, Urrutia G, Asencio G, Stead R, Herrera $C$ (1993) Biochemical composition and nutritive value of suspended particulate matter over a tidal flat of southern Chile. Estuar Coast Shell Sci 37:59-73

Neushul M, Foster MS, Coon CA, Woessner JW, Harger BWW 
(1976) An in situ study of recruitment growth and survival of subtidal marine algae: techniques and preliminary results. J Phycol 12:397-408

Parsons TR (1975) Particulate organic carbon in the sea. In: Riley JP, Skirrow G (eds) Chemical oceanography. Academic Press, London, p 338-425

Peinert R, Saure A, Stegmann P, Stienen C, Haardt $H$, Smetacek V (1982) Dynamics of primary production and sedimentation in a coastal ecosystem. Neth J Sea Res 16: $276-289$

Pocklington R, Leonard JD (1979) Terrigenous organic matter in sediments of the St. Lawrence Estuary and the Saguenay Fjord. J Fish Res Bd Can 36:1250-1255

Posedel N, Faganeli J (1991) Nature and sedimentation of suspended particulate matter during density stratification in shallow coastal waters (Gulf of Trieste, northern Adriatic). Mar Ecol Prog Ser 77:135-145

Poulet SA, Cossa D. Marty JC (1986) Combined analysis of the size spectra and biochemical composition of particles in the St. Lawrence estuary. Mar Ecol Prog Ser 30:205-214

Puškaric S, Fowler SW. Miquel JC (1992) Temporal changes in particulate flux in the Northern Adriatic Sea. Estuar Coast Shelf Sci 35:267-287

Relexans JC, Lin RG, Castel J, Etcheber H, Laborde P (1992) Responses of biota to sedimentary organic matter quality of the West Gironde mud patch, Bay of Biscay (France). Oceanol Acta 15:639-649

Rice SA, Hunter CL (1992) Effects of suspended sediment and burial on scleractinian corals from west central Florida patch reefs. Bull Mar Sci 51:429-442

Rogers CS (1982) The marine environments of Brewers Bay, Perseverance Bay, Flat Cay and Saba Island, St. Thomas, U.S.V.I., with emphasis on coral reefs and seagrass beds. (November 1978-July 1981). Dept of Conservation and Cultural Affairs, Gov't of the Virgin Islands, p 1-181

Rogers CS (1983) Sublethal and lethal effects of sediments applied to common Caribbean reef corals in the field. Mar Pollut Bull 14:378-382

Rogers CS (1990) Responses of coral and reef organisms to sedimentation. Mar Ecol Prog Ser 62:185-202

Scoffin TP (1970) The trapping and binding of subtidal carbonate sediments by marine vegetation in Bimini lagoon, Bahamas. J Sedim Petrol 40:249-273

Seapy RR, Littler MM (1982) Population and species diversity fluctuations in a rocky intertidal community relative to severe aerial exposure and sediment burial. Mar Biol 71. $87-96$

Shaffer JA, Parks DS (1994) Seasonal variation in and observations of landslide impacts on the algal composition of a Puget Sound nearshore kelp forest. Bot Mar 37:315-323

This article was presented by A.J. Southward, Plymouth, UK
Smetacek V (1980) Annual cycle of sedimentation in relation to plankton ecology in western Kiel Bight. Ophelia 1: $65-76$

Smetacek V (1984) The supply of food to the benthos. In Fasham MJR (ed) Flows of energy and materials in marine ecosystems. Theory and practice. Plenum Press, New York, p 517-547

Smetacek V, Von Brockel K, Zeitschel B, Zenk W (1978) Sedimentation of particulate organic matter during a phytoplankton spring bloom in relation to the hydrographical regime. Mar Biol 47:211-226

Sousa WP, Schroeter SC, Gaines SD (1981) Latitudinal variation in intertidal algal community structure: the influence of grazing and vegetative propagation. Oecologia 48 $297-307$

Stephens K, Sheldon RW, Parsons TR (1967) Seasonal variations in the availability of food for benthos in a coasta] environment. Ecology 48:852-855

Stewart JG (1982) Anchor species and epiphytes in intertidal algal turf. Pacif Sci 36:45-59

Stewart JG (1983) Fluctuations in the quantity of sediment trapped among algal thalli on intertidal rock platforms in southern California. J Exp Mar Biol Ecol 73:205-211

Stewart JG (1989) Establishment, persistence and dominance of Corallina (Rhodophyta) in algal turf. J Phycol 25: $436-446$

Strickland JDH, Parsons TR (1972) A practical handbook of seawater analysis (2nd edn). Bull Fish Res Bd Can 167: $1-311$

Taylor PR, Littler MM (1982) The roles of compensatory mortality, physical disturbance, and substrate retention in the development and organization of a sand-influenced, rocky-intertidal community. Ecology 63:135-146

Thom RM, Widdowson TB (1978) A resurvey of a Yale Dawson's 42 intertidal transects on the southern California mainland after 15 years. Bull South Calif Acad Sci 77:1-13

Wassmann P (1985) Sedimentation of particulate material in Nordassvannet, a hypertrophic, land-locked fjord in western Norway. Mar Ecol Prog Ser 22:259-271

Witterberg M. Hunte W (1992) Effects of eutrophication and sedimentation on juvenile corals. I. Abundance, mortality and community structure. Mar Biol 112:131-138

Yap HT (1991) Benthic energy dynamics in a southern Baltic ecosystem. Mar Biol 108:477-484

Young DK, Rhoads DC (1971) Animal-sediment relations in Cape Cod Bay, Massachusetts. I. A transect study. Mar Biol 11:242-254

Zeitzschel B (1970) The quantity, composition and distribution of suspended particulate matter in the Gulf of California. Mar Biol 7:305-318

Manuscript first received: May 3, 1995

Revised version accepted: October 27, 1995 